AL.2.2003.26

c. 2

\title{
EVALUATION OF THE \\ ANTI-OXIDANT \\ ETHYLENE DIUREA (EDU) \\ AS A PROTECTANT \\ AGAINST OZONE EFFECTS \\ ON CROPS
}

(Field Trials) 
Digitized by the Internet Archive in 2016

https://archive.org/details/evaluationofanti00arch 


\title{
EVALUATION OF THE
}

\section{ANTI-OXIDANT ETHYLENE DIUREA (EDU) AS A PROTECTANT AGAINST OZONE EFFECTS ON CROPS}

(Field Trials)

\author{
Prepared by \\ Daniel J. Archambault and Xiaomei Li \\ Climate Change Technologies \\ Alberta Research Council \\ Vegreville, Alberta
}

for

Alberta Environment 
Pub. No: T/697

ISBN No. 0-7785-2518-X (Printed Edition)

ISBN No. 0-7785-2519-8 (On-line Edition)

Web Site: http://www3.gov.ab.ca/env/info/infocentre/publist.cfm

Although prepared with funding from Alberta Environment (AENV), the contents of this report/document do not necessarily reflect the views or policies of AENV, nor does mention of trade names or commercial products constitute endorsement or recommendation for use.

Any comments, questions, or suggestions regarding the content of this document may be directed to:

Science and Standards Branch

Alberta Environment

$4^{\text {th }}$ Floor, Oxbridge Place

$9820-106^{\text {th }}$ Street

Edmonton, Alberta T5K 2J6

Fax: (780) 422-4192

Additional copies of this document may be obtained by contacting:

Information Centre

Alberta Environment

Main Floor, Great West Life Building

$9920-108^{\text {th }}$ Street

Edmonton, Alberta T5K 2M4

Phone: (780) 944-0313

Fax: (780) 427-4407

Email: env.infocent@gov.ab.ca 


\section{FOREWORD}

Ozone differs from the majority of the other common air pollutants in that it is not directly emitted from industrial and urban sources, or as a consequence of other human activity. Stratospheric ozone protects the Earth's surface from harmful UV exposure; however, when present in the troposphere (at "ground-level"), ozone can be harmful to human and plant life. Ground-level ozone is formed as a result of chemical reactions among other pollutants (e.g. nitrogen oxides, volatile organic compounds). These may be emitted into the air naturally or by industrial and personal activity. In addition, atmospheric processes such as tropopause folding or stratospheric intrusion can increase ozone concentrations at the Earth's surface. Tropopause folding moves stratospheric ozone through the tropopause into the upper troposphere. The ozone then travels to the Earth's surface by diffusion and/or convection. Stratospheric intrusion is the result of strong downdrafts induced by synoptic weather systems which carry ozone from the stratosphere to ground-level. Regardless of the source of ground-level ozone, exposure to elevated ozone levels may be harmful to vegetation.

This project presents an approach and preliminary results on the use of a foliarly applied chemical that may protect plants, specifically crops, from harmful effects resulting from elevated ozone exposure. Applications of ethylene diurea (EDU) may provide plants with protection, which could result in increased growth and/or increased crop yield. However, the mechanisms by which EDU protects plants from ozone are not yet understood. The effects of EDU reported here are preliminary, and increased yield in crop plants treated with EDU does not necessarily mean that current levels of ozone are negatively affecting crops. It is possible the effects observed could be a result of physiological mechanisms unrelated to the protective properties of EDU.

This report presents the findings of a preliminary field trial investigating the use of EDU as a protectant of barley, canola and wheat against elevated ozone effects, in the Fort Saskatchewan, Alberta area. These results may be used to design expanded experiments, so that a more complete description of the effects of EDU on crops can be presented. Evaluation of the yields of crops treated with EDU compared to untreated crops grown in a number of areas, which are subjected to differing ozone exposures may help provide an answer to the question "are current elevated levels of ozone in Alberta causing adverse effects in crops?". The results in this report represent the first step in answering this question.

Kenneth R. Foster, Gary Byrtus \& Laura Blair Project Coordinators Air Research Users Group Alberta Environment 


\section{SUMMARY}

Ozone is an important phytotoxic gaseous pollutant and is known or suspected to cause injury in crops, including yield reductions. Studies have been conducted using the antioxidant EDU (ethylene diurea) in programs aimed at the quantification of the effects of ozone on vegetation. For the present study, a protocol making use of EDU as an antioxidant was designed and implemented at a site near the city limits of Fort Saskatchewan, Alberta, an area having elevated ozone levels relative to other areas of the province. The overall objectives of this project were:

- To develop a procedure for the use of EDU on crops grown under field conditions.

- To determine if Alberta crops are being negatively affected by ambient ozone at a single selected site that is likely to experience elevated levels of ground-level ozone.

Two cultivars each of wheat (Triticum aestivum), barley (Hordeum vulgare), canola (Brassica napus) and field pea (Pisum sativum) were used in this study. Ozone concentrations and the trend in changes in ozone concentrations over the experimental period were typical for Fort Saskatchewan.

The experiment was set-up as a split-split plot design. Plots were treated with either 0, 150, 300 or $450 \mathrm{ppm}$ EDU eight times throughout the experimental period at approximately 14-day intervals. No obvious visual symptoms of ozone or of EDU were observed. While treatment with EDU caused increases in several parameters measured, few of these effects proved to be statistically significant. Responses were species- and cultivar-specific but in most cases, increases were greatest at the lowest EDU concentration $(150 \mathrm{ppm})$. This might suggest that greater effects would have been achieved at lower EDU concentrations. EDU effects may result from protection against ozone injury or from EDU-induced enhancement in plant growth that is unrelated to protection against ozone exposure. An examination of EDU effects in the presence and absence of ozone under controlled conditions (e.g. growth chambers) is recommended to separate and examine the effects of EDU as a protectant against ozone effects and the effects of EDU independent of ozone exposure.

In future experiments, consideration should be given to reducing the lowest concentration of EDU, perhaps to $75 \mathrm{ppm}$. While interesting trends emerged from this study, statistical significance of EDU effects was rarely found. This suggests that the power of the experiment should be increased. This could be achieved by increasing the number of replicates, the size of plots and/or the number of sub-samples taken from each plot. This field experiment should be repeated at multiple sites in Alberta to gain information on spatial and seasonal variation of ozone and resulting ozone effects, and on the possible protection of crops against ozone exposure using EDU. As a preliminary trial, the results of this experiment are not sufficient to conclude that there are, or are not, effects of ozone on crops in Alberta. 


\section{TABLE OF CONTENTS}

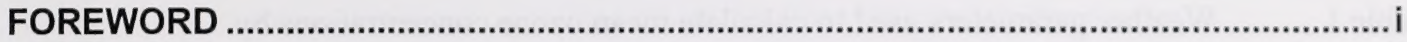

SUMMARY

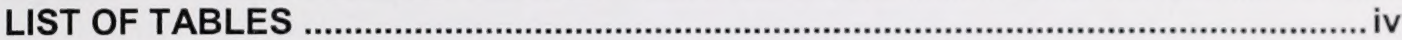

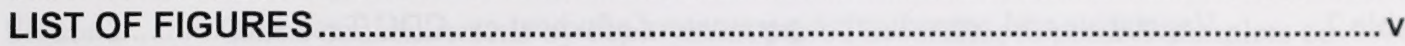

ACKNOWLEDGEMENTS ......................................................................................... vi

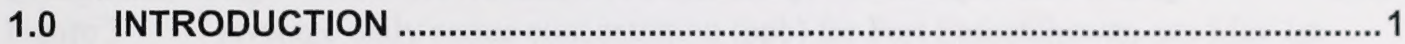

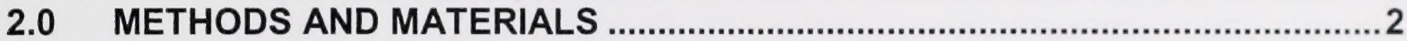

2.1 Site Selection, Ozone Monitoring and Weather Information ................................2

2.2 Crop Selection, EDU Treatments and Experimental Design ................................. 3

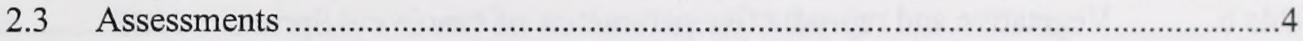

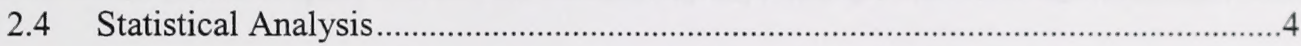

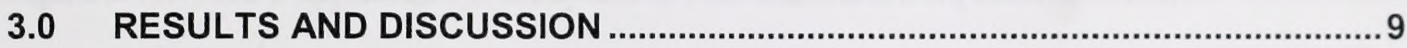

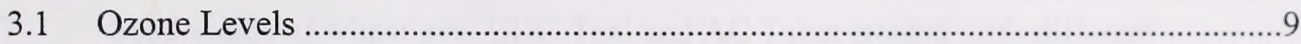

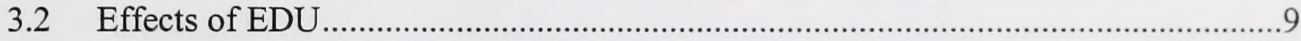

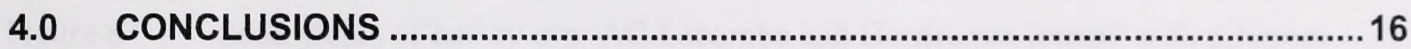

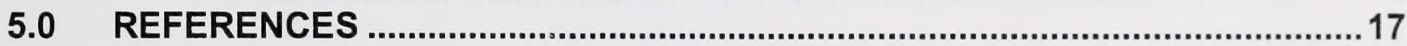




\section{LIST OF TABLES}

Table 1 Weather parameters used to calculate mean ozone concentrations by deployment period from passive monitors..................................................................

Table 2 Vegetative and reproductive parameters of wheat $\mathrm{cv}$. CDC Teal..............................9

Table 3 Vegetative and reproductive parameters of wheat cv. AC Taber .............................11

Table $4 \quad$ Vegetative and reproductive parameters of barley cv. AC Lacombe ........................11

Table $5 \quad$ Vegetative and reproductive parameters of barley cv. Harrington .............................12

Table 6 Vegetative and reproductive parameters of canola cv. Sprint ..................................15

Table $7 \quad$ Vegetative and reproductive parameters of canola cv. Quantum ..............................15 


\section{LIST OF FIGURES}

Figure 1 Passive samplers mounted within a rain shelter. .3

Figure 2 Ozone concentrations by deployment period according to passive samplers on site and AENV continuous monitor approximately $1.5 \mathrm{~km}$ away.... 5

Figure 3 Average daily ozone concentration ( $\mathrm{ppb}$ ) for Fort Saskatchewan site May 1st - September 30th, 2000

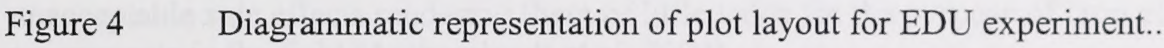
6

Figure $5 \quad$ EDU/ozone study site at Fort Saskatchewan, Alberta ......................................

Figure $6 \quad$ EDU application at study site at Fort Saskatchewan, Alberta .............................

Figure 7 Seed yields of wheat cvs. CDC Teal and AC Taber treated with different levels of EDU

Figure 8 Seed yields of barley cvs. AC Lacombe and Harrington treated with different levels of EDU

Figure 9 Seed yields of canola cvs. Sprint and Quantum treated with different levels of EDU 


\section{ACKNOWLEDGEMENTS}

This project was supported by funds from Alberta Environment. The authors gratefully acknowledge the contributions of Ken Foster, Gary Byrtus and Laura Blair to this report. The authors also thank Jim Storey, Dayna MacIntyre, Trish Rattray, Marlene Boissoneau, Karen Sorensen and Jan Slaski for their technical help with this project. 


\section{$1.0 \quad$ INTRODUCTION}

Ozone is an important phytotoxic gaseous pollutant in Canada, the USA and many other industrialized countries. Attempts to protect plants using various chemical substances have been made. Protection may be achieved by coating the leaf surface and providing physical and or chemical protection, through the alteration of gas exchange or through the alteration of plant metabolism. Several studies suggest that the application of certain chemical protectants against ozone might be a reliable means by which to assess crop effects under field conditions. Manning and Krupa (1992) presented a list of examples of chemicals used to protect plants from ozone injury with references spanning from 1960 to 1991. While many chemicals have been shown to convey partial or total protection against ozone injury, many are ineffective and have unacceptable side effects rendering them of little value for the purpose of crop effects assessments in the field (Archambault et al. 2000).

Through the late 1980's and into the 1990's EDU (ethylene diurea) has been used under a number of conditions as a protectant from ozone injury (Archambault et al. 2000). Researchers reported that EDU reduced and/or delayed the appearance of ozone damage to developing foliage and delayed plant senescence and leaf abscission. These findings showed promise for the use of EDU as a general protectant against ozone damage but in order to be useful as a tool for the determination of crop losses due to ozone exposure, it was also necessary to verify whether EDU caused side effects in the absence of ozone. The possible side effects of EDU were discussed by Legassicke and Ormrod (1981) and Foster et al. (1983).

Studies have been conducted to establish optimized protocols for the use of EDU in programs aiming at the quantification of the effects of ozone on vegetation and to understand the process by which EDU conveys protection against ozone. The effects of EDU are species- and sometimes cultivar-specific, and the concentration, frequency and mode of application are critical considerations. In designing an EDU treatment regime, it is also important to consider the length and frequency of ozone exposure as well as environmental conditions (Manning, 1995).

Based on the literature, a protocol making use of EDU as an antioxidant was designed and implemented at a site near the city limits of Fort Saskatchewan, Alberta, an area having elevated ozone levels relative to other areas of the province. The objectives of this project were:

- To develop a procedure for the use of EDU on crops grown under field conditions.

- To determine if Alberta crops are being negatively affected by ambient ozone at a single selected site that is likely to experience elevated levels of ground-level ozone.

The results of this study provide an indication of the usefulness of EDU in a large-scale examination of ozone effects on agricultural crops in Alberta. 


\subsection{METHODS AND MATERIALS}

\subsection{SITE SELECTION, OZONE MONITORING AND WEATHER INFORMATION}

Based upon provincial ozone monitoring data, the Fort Saskatchewan, Alberta area was identified as a site with a high probability of experiencing relatively high ozone levels. A suitable agricultural site $\left(53^{\circ} 43^{\prime} / 113^{\circ} 13^{\prime}\right)$ on the city limits of Fort Saskatchewan was selected. The site had previously been sown to field pea.

Ozone levels were monitored at the research site throughout the growing season using passive samplers (Maxxam Analytics Inc.). Passive devices were deployed for periods of approximately two weeks from May 26 to September 14. Three replicate samplers were mounted within each of two rain shelters (Figure 1) installed atop posts at a height of $3 \mathrm{~m}$ above-ground level at the east and west boundaries of the 2 ha site. The site was approximately $1.5 \mathrm{~km}$ (SSW) from an Alberta Environment air quality monitoring station equipped with a continuous ozone monitor. Hourly ozone data were downloaded from the Clean Air Strategic Alliance (CASA, 2000) web site and mean values were computed for the periods of deployment of passive samplers. Mean daily values were also computed. Ozone values from continuous sampling and passive samplers are compared in Figure 2. Average daily ozone data are shown in Figure 3. The calculation of ozone concentrations using passive samplers requires average air temperature, relative humidity and wind speed for the deployment period. Temperature and relative humidity were monitored using Hobo sensors and wind speed was measured using an RM Young wind sensor - the monitoring devices were connected to a portable continuous meteorological data recording device. This information (Table 1) was supplied to Maxxam Analytics Inc. who then computed average ozone concentrations for each deployment period.

Table 1 Weather parameters used to calculate mean ozone concentrations by deployment period from passive monitors

\begin{tabular}{|c|c|c|c|}
\hline Deployment Periods & Avg. Wind Speed $(\mathbf{k m} / \mathbf{h})$ & Avg. RH (\%) & Avg. Temp $\left({ }^{\circ} \mathbf{C}\right)$ \\
\hline May 26 - June 09 & 7.59 & 56.5 & 12.9 \\
\hline June 09 - June 22 & 9.27 & 76.8 & 11.7 \\
\hline June 22 - July 06 & 6.73 & 72.7 & 15.0 \\
\hline July 06 - July 21 & 6.70 & 81.9 & 16.0 \\
\hline July 21 - August 04 & 6.53 & 77.2 & 18.3 \\
\hline August 04 - August 18 & 7.39 & 76.1 & 15.4 \\
\hline August 18 - August 31 & 7.47 & 73.3 & 13.4 \\
\hline August 31- September 14 & 8.77 & 77.9 & 10.0 \\
\hline
\end{tabular}




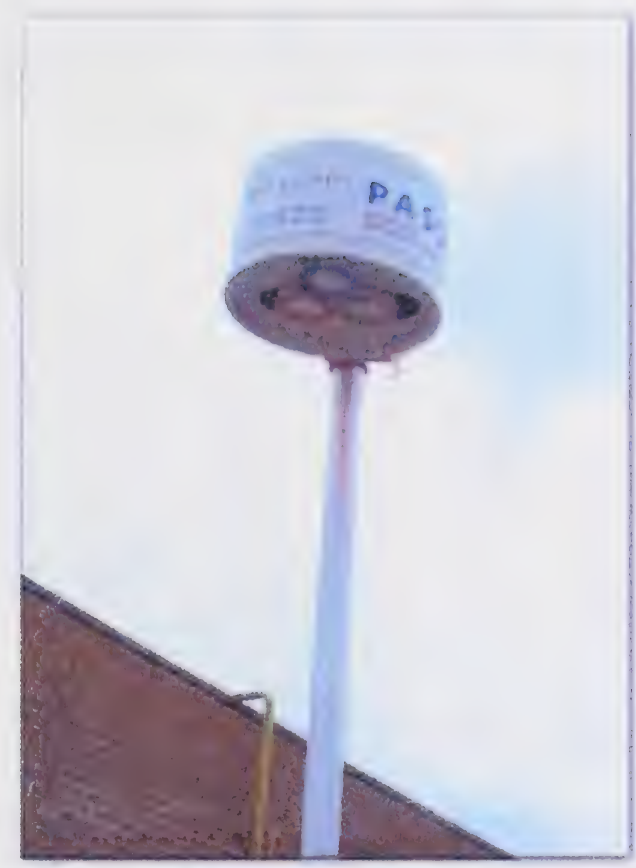

Photograph from Maxxam Analytics Inc. web site

Figure 1 Passive samplers mounted within a rain shelter

\subsection{CROP SELECTION, EDU TREATMENTS AND EXPERIMENTAL DESIGN}

Two cultivars each of four regionally common crops were selected for this study. They were:

- wheat (Triticum aestivum) cvs. CDC Teal and AC Taber,

- barley (Hordeum vulgare) cvs. AC Lacombe and Harrington,

- canola (Brassica napus) cvs. Sprint and Quantum and

- field pea (Pisum sativum) cvs. Carneval and Carrera.

A split-split plot design (Little and Hills, 1978) was used for this experiment, with EDU treatments as the main plot, crop as the sub-plot, and cultivar as the sub-sub-plot, and with four replicates (Figures 4 and 5). Main plots were arranged randomly within each replicate. A total of 128 plots were utilized.

Two sequential Round-up (2.5\% solution) burn-offs were performed, one two weeks prior to seeding and the other two days after seeding. Seeds were sown in rows within plots measuring $2 \mathrm{~m} \times 5 \mathrm{~m}$. Following emergence, and at 14-day intervals, plants were treated with solution containing either $0,150,300$ or $450 \mathrm{ppm}$ EDU in water as a foliar spray applied to run-off. EDU treatments were applied in a single pass using a sprayer with a $5 \mathrm{~m}$ boom (Figure 6). The sprayer 
pressure was maintained constant and the speed used to apply the treatments was calibrated on buffer vegetation so as to ensure application to run-off. A $2 \mathrm{~m}$ buffer strip was left between treatment blocks to minimize drift of the solution into the adjacent blocks. Buffer areas between the plots and on the remainder of the site were sown to oats $\mathrm{cv}$. Cascade.

\subsection{ASSESSMENTS}

Plants were examined bi-weekly throughout the vegetation period for symptoms of ozone damage and EDU toxicity and/or protection. Photographic records were kept. Pea treatments were totally compromised by weed infestations and no data were generated from these plots. At the end of the season $1 \mathrm{~m} \times 3 \mathrm{~m}$ quadrats were established within each $2 \mathrm{~m} \times 5 \mathrm{~m}$ plot and divided into three $1 \mathrm{~m} \mathrm{x} 1 \mathrm{~m}$ sub-quadrats. The heights of the four tallest plants in each subquadrat (12 measurements per plot) were recorded prior to harvest. Above-ground biomass within the center sub-quadrat was harvested manually, dried in an oven at $70^{\circ} \mathrm{C}$ and weighed. Samples were threshed and the seeds were extracted, weighed and counted, and the weight per thousand seeds (seed size) was calculated.

\section{$2.4 \quad$ STATISTICAL ANALYSIS}

Data were entered into Excel worksheets and means, standard deviations and standard errors were computed. Data were analyzed by cultivar with SAS (Version 8.01) using PROC MIXED and the Dunnett's test (comparing treatments with a control). 


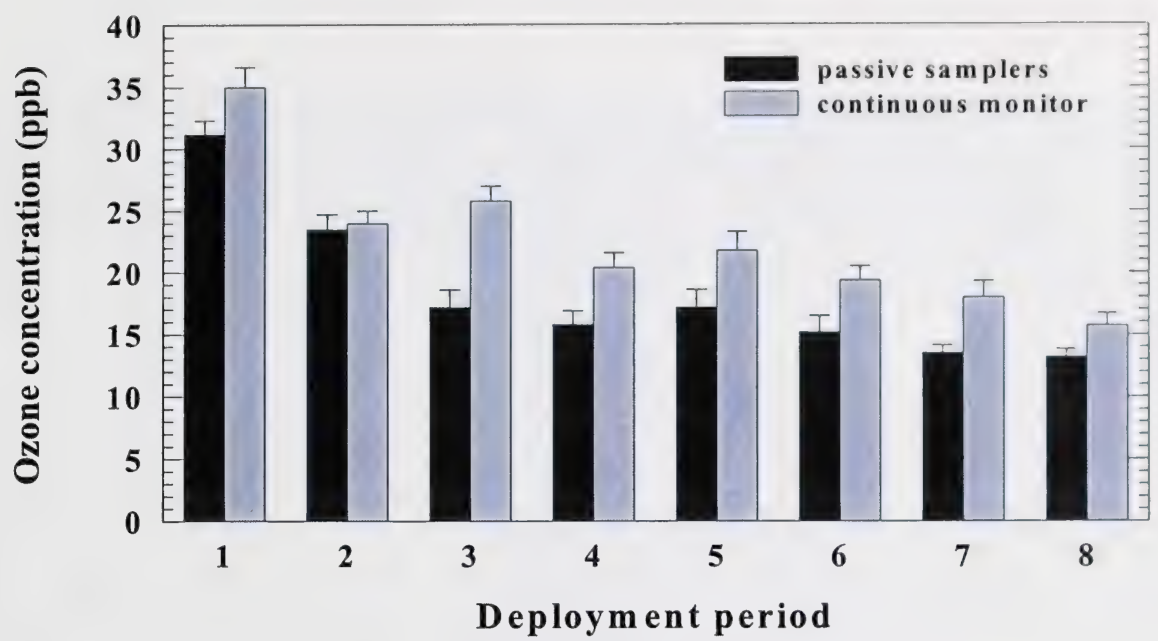

Deployment periods were: May 26 - June 09 (1), June 09 - June 22 (2), June 22 - July 06 (3), July 06 - July 21 (4), July 21 - August 04 (5), August 04 - August 18 (6), August 18 - August 31 (7) and August 31 - September 14 (8)

Figure 2 Ozone concentrations by deployment period according to passive samplers on site and AENV continuous monitor approximately $1.5 \mathrm{~km}$ away

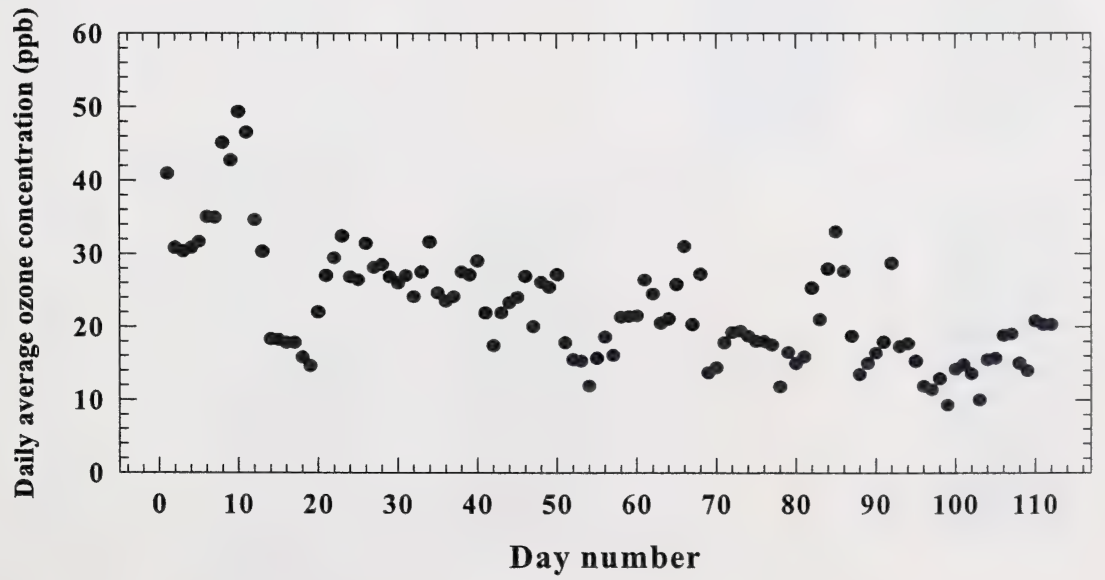

Figure 3 Average daily ozone concentration (ppb) for Fort Saskatchewan site May 1st - September 30th, 2000 

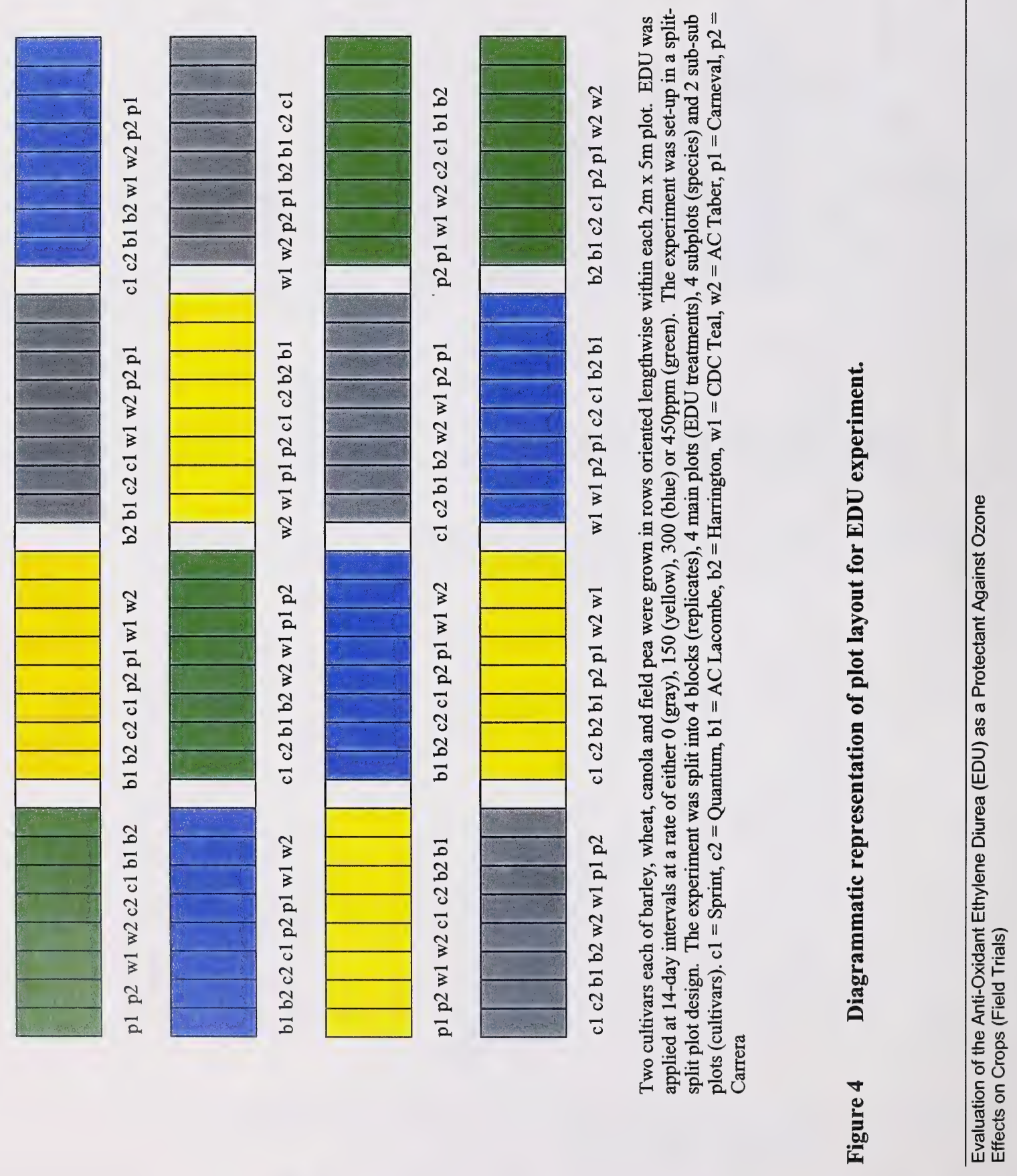


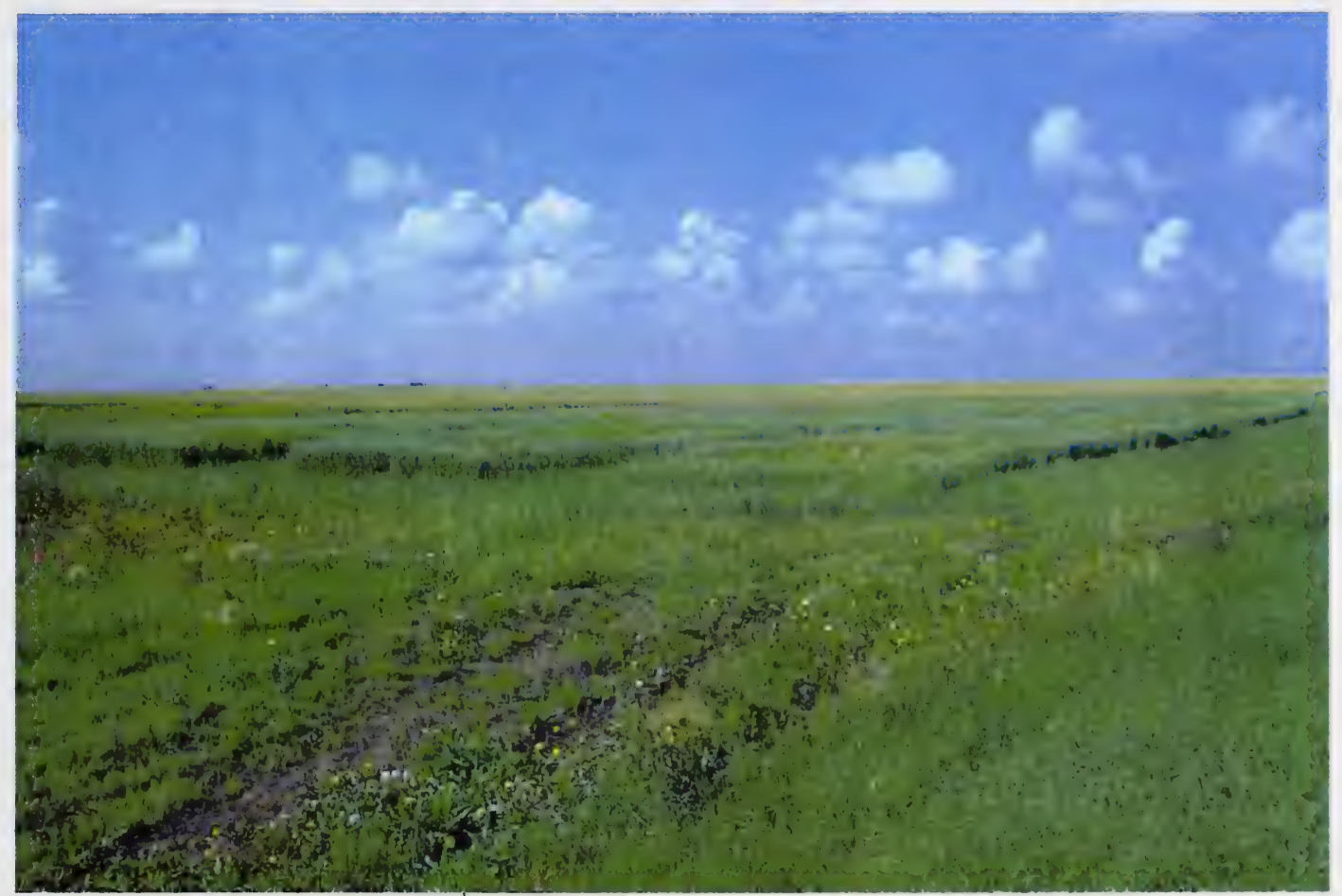

Photograph taken on August $4^{\text {th }}, 2000$ from Northeast corner of the site. Block $\# 1$ is nearest

Figure 5 EDU/ozone study site at Fort Saskatchewan, Alberta 


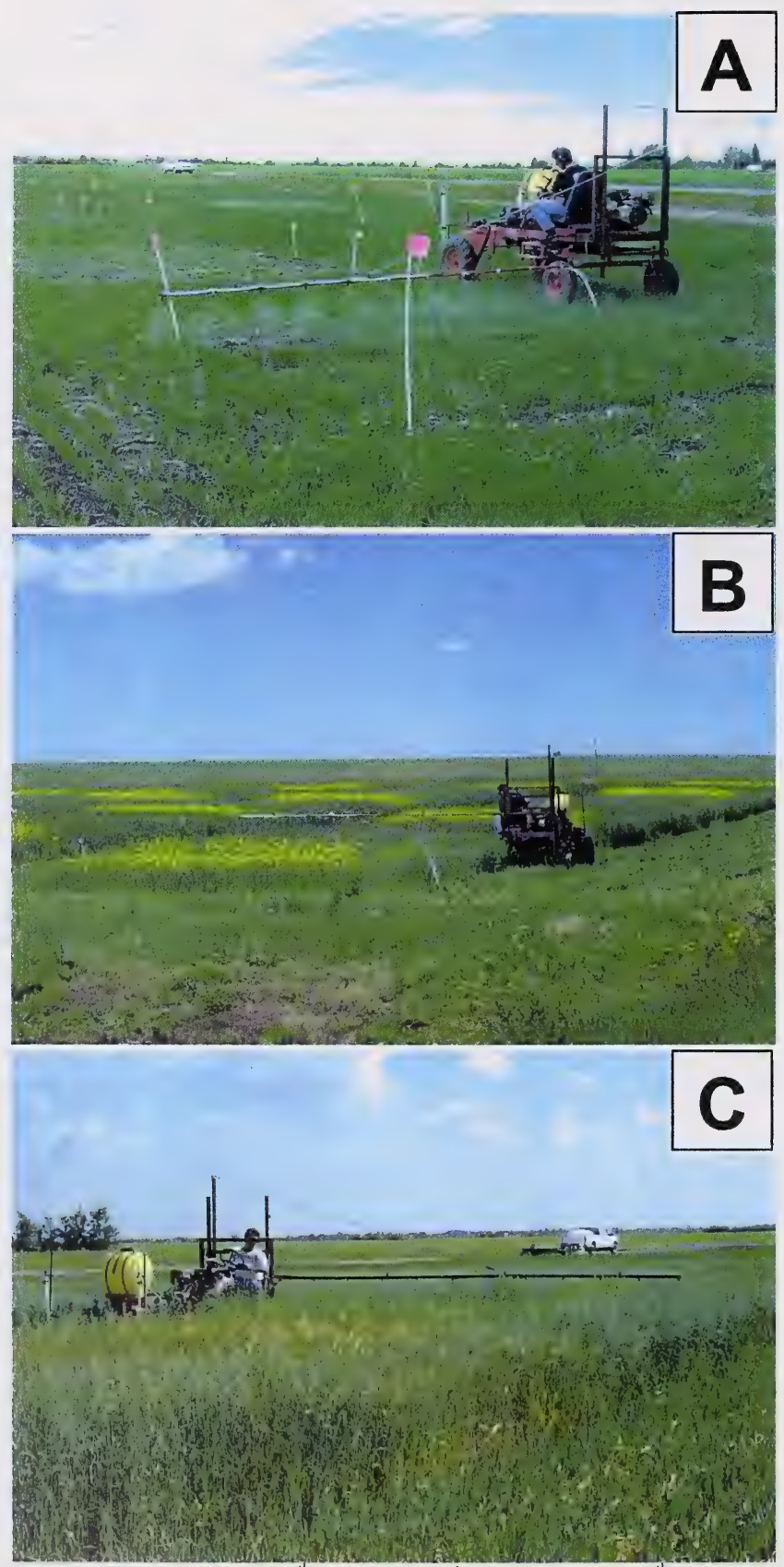

Photographs were taken on (A) June $9^{\text {th }}$, (B) July $21^{\text {st }}$ and (C) August $4^{\text {th }}, 2000$

Figure $6 \quad$ EDU application at study site at Fort Saskatchewan, Alberta 


\subsection{RESULTS AND DISCUSSION}

\subsection{OZONE LEVELS}

The ozone concentration values obtained using passive samplers (Maxxam Analytics Inc.) and the averages calculated for the same time periods using the data from the nearby AENV continuous monitoring station were similar - both measures indicated higher spring-time ozone levels which tended to decrease as the season progressed (Figure 2). The passive sampler system consistently resulted in a lower average ozone concentration than the continuous system. The ozone concentrations and pattern of changes in concentration over the period monitored are typical for Fort Saskatchewan (Sandhu, 1999). The average ozone concentration for the first deployment period was affected by 5 days where daily average concentrations were above 40 ppb (Figure 3 ). The average for the second deployment period was affected by 6 days where daily averages were below $20 \mathrm{ppb}$. Daily averages fluctuated between 12 and $32 \mathrm{ppb}$ in the period of flowering and early maturation days 50 to 90 (Figure 3 ). According to the literature, these ozone levels would be sufficient to cause effects in certain plant species (Archambault et al., 2000).

\section{$3.2 \quad$ EFFECTS OF EDU}

In wheat $\mathrm{cv}$. CDC Teal, plant height was significantly increased by treatment with EDU at a concentration of $300 \mathrm{ppm}$ (Table 2). Above-ground biomass (Table 2), seed yield (Figure 7), seed number and seed size (Table 2) were all greater in plants treated with EDU at a concentration of $150 \mathrm{ppm}$ but these effects were not statistically significant. In wheat $\mathrm{cv}$. AC Taber plant heights were not significantly affected by treatment with EDU while above-ground biomass increased significantly in plants treated with $150 \mathrm{ppm}$ EDU (Table 3 ). Seed yields increased significantly when plants were treated with $150 \mathrm{ppm}$ EDU (Figure 7). The increase in yield at $150 \mathrm{ppm}$ EDU is exclusively due to increased seed numbers rather than size (Table 3 ). Seed size was significantly increased in plants treated with 300 and 450 ppm EDU (Table 3).

Table 2 Vegetative and reproductive parameters of wheat cv. CDC Teal

\begin{tabular}{|c|c|c|c|c|}
\hline $\begin{array}{c}\text { EDU Conc. } \\
(\mathrm{ppm})\end{array}$ & $\begin{array}{c}\begin{array}{c}\text { Plant Height } \\
(\mathrm{cm})\end{array} \\
\end{array}$ & $\begin{array}{c}\text { AG Biomass } \\
(\mathrm{g}) \\
\end{array}$ & Seed Number & $\begin{array}{c}\text { Seed Size }(\mathrm{g}) \\
\text { (weight per } 1000 \text { seeds) }\end{array}$ \\
\hline 0 & $\begin{array}{l}105.2 \pm 0.5 \\
\mathrm{~A}\end{array}$ & $\begin{array}{l}747.0 \pm 35.5 \\
\mathrm{~A}\end{array}$ & $\begin{array}{l}9944 \pm 557 \\
\text { A }\end{array}$ & $\begin{array}{l}31.6 \pm 0.8 \\
\mathrm{~A}\end{array}$ \\
\hline 150 & $\begin{array}{l}107.0 \pm 0.3 \\
\text { A }\end{array}$ & $\begin{array}{l}832.5 \pm 58.1 \\
\mathrm{~A}\end{array}$ & $\begin{array}{l}10922 \pm 609 \\
\mathrm{~A}\end{array}$ & $\begin{array}{l}32.9 \pm 0.6 \\
\mathrm{~A}\end{array}$ \\
\hline 300 & $\begin{array}{l}108.8 \pm 0.4 \\
B\end{array}$ & $\begin{array}{l}718.6 \pm 43.1 \\
\text { A }\end{array}$ & $\begin{array}{l}9224 \pm 801 \\
\text { A }\end{array}$ & $\begin{array}{l}32.9 \pm 0.6 \\
\mathrm{~A}\end{array}$ \\
\hline 450 & $\begin{array}{l}108.6 \pm 0.5 \\
\text { A }\end{array}$ & $\begin{array}{l}757.2 \pm 34.4 \\
\text { A }\end{array}$ & $\begin{array}{l}10248 \pm 747 \\
\text { A }\end{array}$ & $\begin{array}{l}32.9 \pm 1.2 \\
\mathrm{~A}\end{array}$ \\
\hline
\end{tabular}

Values are means $\pm \mathrm{SE}$. Within each column, values bearing letters that differ from controls ( 0 ppm EDU) are significantly different at $\mathrm{P} \geq 0.95$. Plant heights, $\mathrm{N}=48$; all others $\mathrm{N}=3$ or 5 

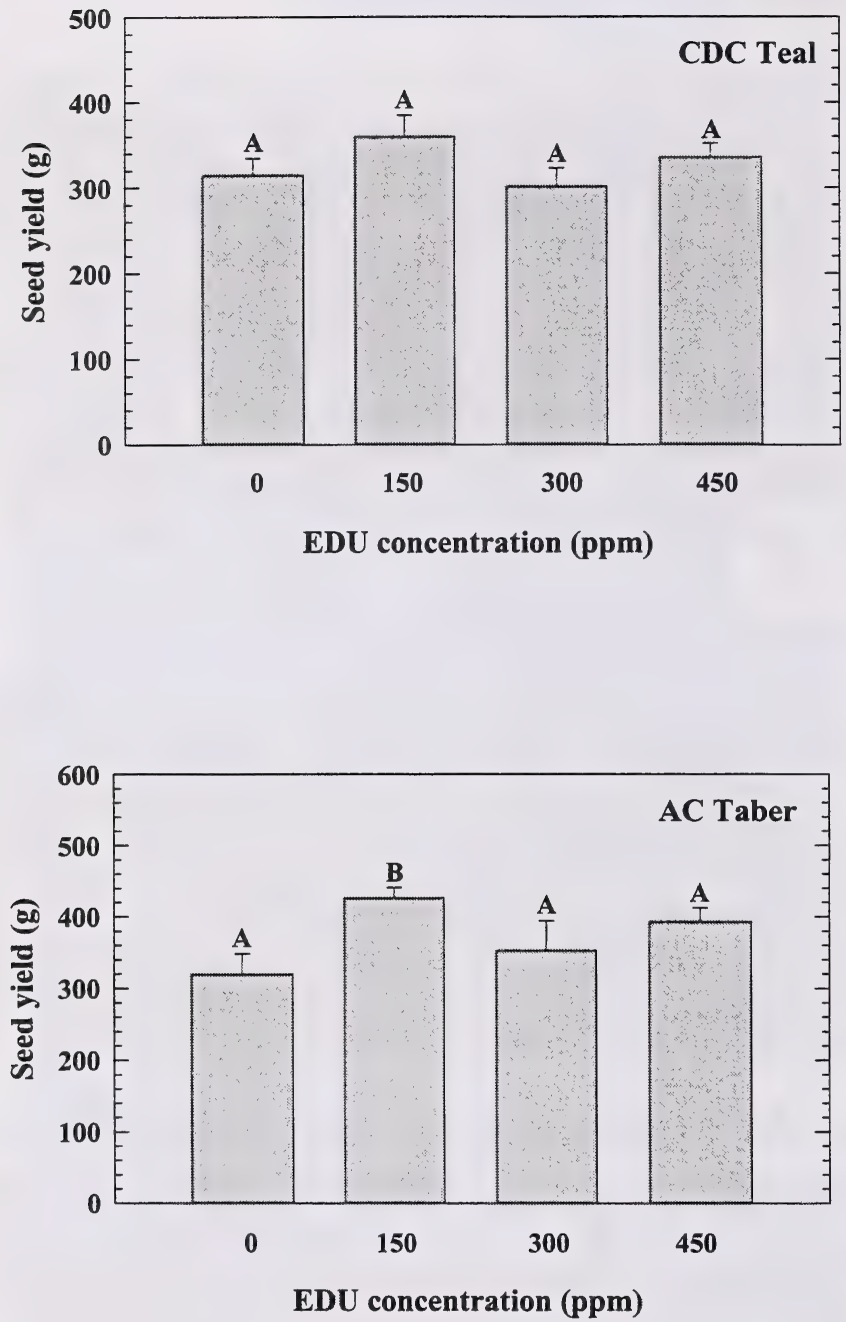

Values are means $\pm \mathrm{SE}$. Bars bearing letters that differ from controls $(0 \mathrm{ppm}$ EDU) are significantly different at $\mathrm{P} \geq 0.95 . \mathrm{N}=3$ or 5

Figure 7 Seed yields of wheat cvs. CDC Teal and AC Taber treated with different levels of EDU 
Table $3 \quad$ Vegetative and reproductive parameters of wheat $\mathrm{cv}$. AC Taber

\begin{tabular}{|c|c|c|c|c|}
\hline $\begin{array}{l}\text { EDU Conc. } \\
\quad(p p m)\end{array}$ & $\begin{array}{l}\text { Plant Height } \\
(\mathrm{cm})\end{array}$ & $\begin{array}{c}\text { AG Biomass } \\
\text { (g) }\end{array}$ & Seed Number & $\begin{array}{c}\text { Seed Size }(\mathrm{g}) \\
\text { (weight per } 1000 \\
\text { seeds) }\end{array}$ \\
\hline$\overline{0}$ & $\begin{array}{l}99.3 \pm 0.5 \\
\text { A }\end{array}$ & $\begin{array}{l}732.1 \pm 60.4 \\
\text { A }\end{array}$ & $\begin{array}{l}8243 \pm 930 \\
\text { A }\end{array}$ & $\begin{array}{l}39.2 \pm 1.0 \\
\text { A }\end{array}$ \\
\hline 150 & $\begin{array}{l}102.0 \pm 0.5 \\
A\end{array}$ & $\begin{array}{l}945.8 \pm 42.0 \\
B\end{array}$ & $\begin{array}{l}11088 \pm 487 \\
B\end{array}$ & $\begin{array}{l}38.6 \pm 0.9 \\
A\end{array}$ \\
\hline 300 & $\begin{array}{l}99.1 \pm 0.4 \\
\text { A }\end{array}$ & $\begin{array}{l}818.0 \pm 80.9 \\
\text { A }\end{array}$ & $\begin{array}{l}8281 \pm 912 \\
\text { A }\end{array}$ & $\begin{array}{l}42.5 \pm 0.5 \\
B\end{array}$ \\
\hline 450 & $\begin{array}{l}98.8 \pm 0.7 \\
A\end{array}$ & $\begin{array}{l}881.7 \pm 35.7 \\
\text { A }\end{array}$ & $\begin{array}{l}9245 \pm 613 \\
\text { A }\end{array}$ & $\begin{array}{l}42.7 \pm 0.9 \\
B\end{array}$ \\
\hline
\end{tabular}

Values are means \pm SE. Within each column, values bearing letters that differ from controls ( 0 ppm EDL) are significantly different at $P \geq 0.95$. Plant heights, $N=48$; all others $N=3$ or 5

Table 4 Vegetative and reproductive parameters of barley cv. AC Lacombe

\begin{tabular}{|c|c|c|c|c|}
\hline $\begin{array}{l}\text { EDU Conc. } \\
\text { (ppm) }\end{array}$ & $\begin{array}{l}\text { Plant Height } \\
\text { (cm) }\end{array}$ & $\begin{array}{l}\text { AG Biomass } \\
\text { (g) }\end{array}$ & Seed Number & $\begin{array}{c}\text { Seed Size }(\mathrm{g}) \\
\text { (weight per } 1000 \text { seeds) }\end{array}$ \\
\hline 0 & $\begin{array}{l}89.4 \pm 0.9 \\
\text { A }\end{array}$ & $\begin{array}{l}683.3 \pm 56.4 \\
\text { A }\end{array}$ & $\begin{array}{l}9921 \pm 823 \\
\text { A }\end{array}$ & $\begin{array}{l}36.0 \pm 0.7 \\
\mathrm{~A}\end{array}$ \\
\hline 150 & $\begin{array}{l}93.5 \pm 1.0 \\
\mathrm{~A}\end{array}$ & $\begin{array}{l}783.7 \pm 88.1 \\
\text { A }\end{array}$ & $\begin{array}{l}11592 \pm 1414 \\
\text { A }\end{array}$ & $\begin{array}{l}35.6 \pm 0.3 \\
\mathrm{~A}\end{array}$ \\
\hline 300 & $\begin{array}{l}92.3 \pm 0.9 \\
\text { A }\end{array}$ & $\begin{array}{l}781.1 \pm 77.9 \\
\text { A }\end{array}$ & $\begin{array}{l}10389 \pm 932 \\
\text { A }\end{array}$ & $\begin{array}{l}38.4 \pm 0.5 \\
B\end{array}$ \\
\hline 450 & $\begin{array}{l}90.9 \pm 0.6 \\
\text { A }\end{array}$ & $\begin{array}{l}759.3 \pm 38.4 \\
\text { A }\end{array}$ & $\begin{array}{l}9885 \pm 417 \\
\text { A }\end{array}$ & $\begin{array}{l}38.8 \pm 0.4 \\
B\end{array}$ \\
\hline
\end{tabular}

Values are means $\pm \mathrm{SE}$. Within each column, values bearing letters that differ from controls ( $0 \mathrm{ppm}$ EDU) are significantly different at $P \geq 0.95$. Plant heights, $N=48$; all others $N=4$

In barley cv. AC Lacombe, while plant heights (Table 4), seed yield (Figure 8), above-ground biomass and seed number (Table 4) were all greater in plants treated with EDU at a concentration of $150 \mathrm{ppm}$, none of these effects were statistically significant. Seed size increased significantly in plants treated with 300 and $450 \mathrm{ppm}$ EDU (Table 4) but the effects were not large enough to cause significant increases in yield. In barley cv. Harrington, all parameters measured (Figure 8, Table 5) were greater in plants treated with EDU at a concentration of $150 \mathrm{ppm}$ but none of these effects were statistically significant. 
Table 5 Vegetative and reproductive parameters of barley cv. Harrington

\begin{tabular}{|l|l|l|l|l|}
\hline $\begin{array}{c}\text { EDU Conc. } \\
(\mathbf{p p m})\end{array}$ & \multicolumn{1}{|c|}{$\begin{array}{c}\text { Plant Height } \\
(\mathbf{c m})\end{array}$} & \multicolumn{1}{|c|}{$\begin{array}{c}\text { AG Biomass } \\
\mathbf{( g )}\end{array}$} & \multicolumn{1}{|c|}{ Seed Number } & \multicolumn{1}{|c|}{$\begin{array}{l}\text { Seed Size (g) } \\
\text { (weight per 1000 } \\
\text { seeds) }\end{array}$} \\
\hline \hline 0 & $\begin{array}{l}83.1 \pm 0.5 \\
\mathrm{~A}\end{array}$ & $\begin{array}{l}779.8 \pm 55.1 \\
\mathrm{~A}\end{array}$ & $\begin{array}{l}9544 \pm 705 \\
\mathrm{~A}\end{array}$ & $\begin{array}{l}40.9 \pm 0.5 \\
\mathrm{~A}\end{array}$ \\
\hline 150 & $88.5 \pm 1.3$ & $\begin{array}{l}824.6 \pm 109.3 \\
\mathrm{~A}\end{array}$ & $\begin{array}{l}10071 \pm 1183 \\
\mathrm{~A}\end{array}$ & $\begin{array}{l}41.4 \pm 0.9 \\
\mathrm{~A}\end{array}$ \\
\hline 300 & $\begin{array}{l}\mathrm{A} \\
\mathrm{A}\end{array}$ & $\begin{array}{l}748.9 \pm 75.8 \\
\mathrm{~A}\end{array}$ & $\begin{array}{l}9404 \pm 785 \\
\mathrm{~A}\end{array}$ & $\begin{array}{l}39.8 \pm 1.2 \\
\mathrm{~A}\end{array}$ \\
\hline 450 & $86.9 \pm 0.8$ & $\begin{array}{l}729.1 \pm 27.6 \\
\mathrm{~A}\end{array}$ & $\begin{array}{l}8753 \pm 457 \\
\mathrm{~A}\end{array}$ & $\begin{array}{l}41.2 \pm 0.5 \\
\mathrm{~A}\end{array}$ \\
\hline
\end{tabular}

Values are means \pm SE. Within each column, values bearing letters that differ from controls ( $0 \mathrm{ppm}$ EDU) are significantly different at $P \geq 0.95$. Plant heights, $N=48$; all others $N=4$

In canola cv. Sprint, plant height, above-ground biomass (Table 6) and seed yields (Figure 9) were all increased by treatment with EDU but none of these effects were statistically significant. Seed number was increased in plants treated with EDU at concentrations of 150 and $300 \mathrm{ppm}$ (Table 6) but these effects were not statistically significant. No effects on seed seize were observed (Table 6). No statistically significant effects of EDU were observed in canola cv. Quantum (Figure 9, Table 7) although seed yield and seed number increased by approximately 38 and $48 \%$, respectively, when plants were treated with EDU at a concentration of $150 \mathrm{ppm}$ (Figure 9, Table 7).

No useful data were obtained for field pea due to an uncontrollable outbreak of weed growth. Field pea did not compete well with weeds at this site. All cultivars of wheat, barley and canola used in this study responded to EDU treatment by either increasing vegetative or reproductive growth, or both. Effects and trends were species- and cultivar-specific. On rare occasions EDU caused decreases in growth at the higher rates of application. In most cases, EDU application at a rate of $150 \mathrm{ppm}$ caused the greatest increases in both vegetative and reproductive growth. This suggests that lower concentrations of EDU might cause further increases in crop growth and yield. The lack of statistical significance of EDU effects that was commonly observed may be due to high variance that was found in both treatments and controls.

EDU effects may result from protection against ozone injury or from enhancement in plant growth. Several studies have shown EDU to protect plants against ozone (Archambault et al., 2000). This remains to be tested in the species and cultivars used in this study. The use of EDU as a method of monitoring for ozone effects on vegetation appears promising and further studies are justified. 

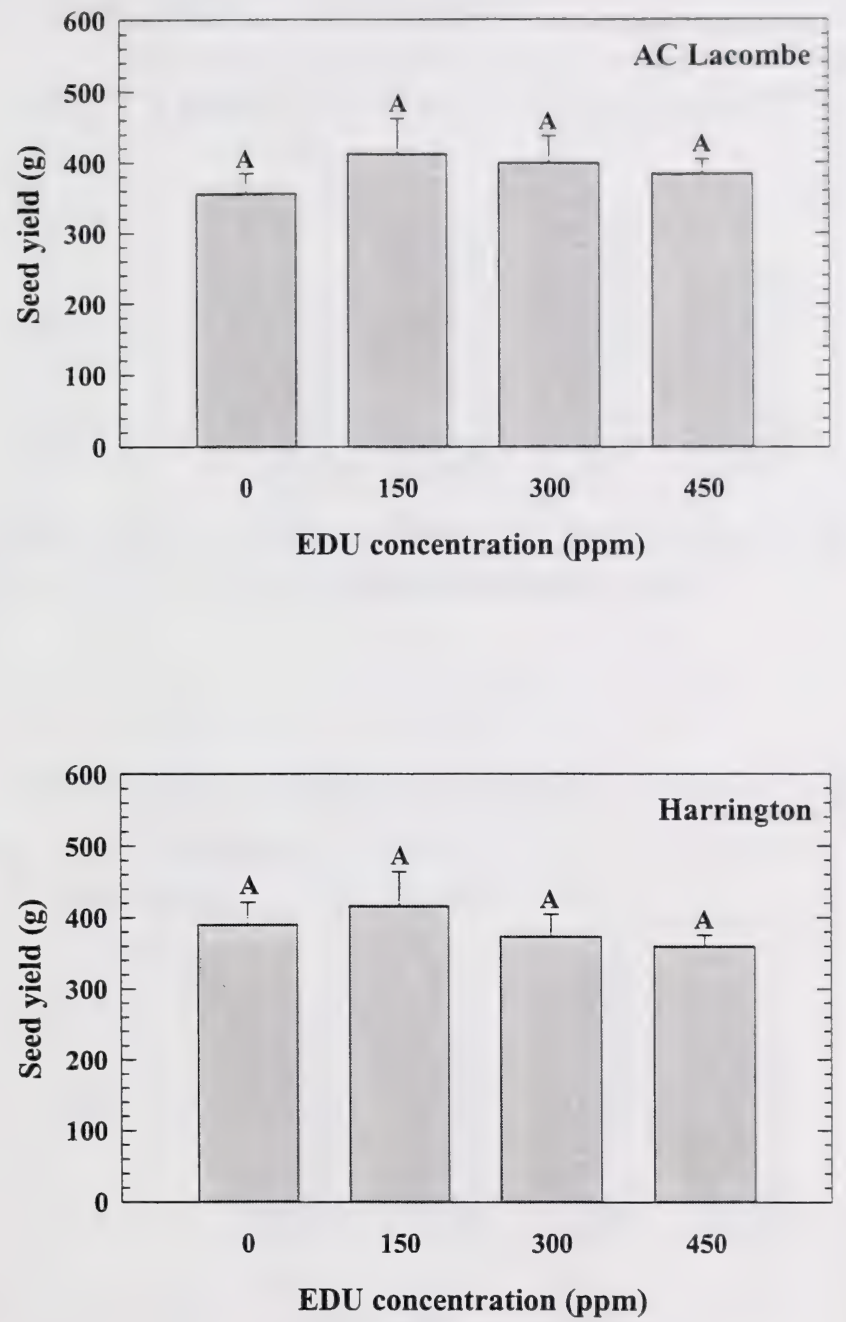

Values are means $\pm \mathrm{SE}$. Bars bearing letters that differ from controls ( $0 \mathrm{ppm}$ EDU) are significantly different at $\mathrm{P} \geq 0.95 . \mathrm{N}=4$

Figure 8 Seed yields of barley cvs. AC Lacombe and Harrington treated with different levels of EDU 

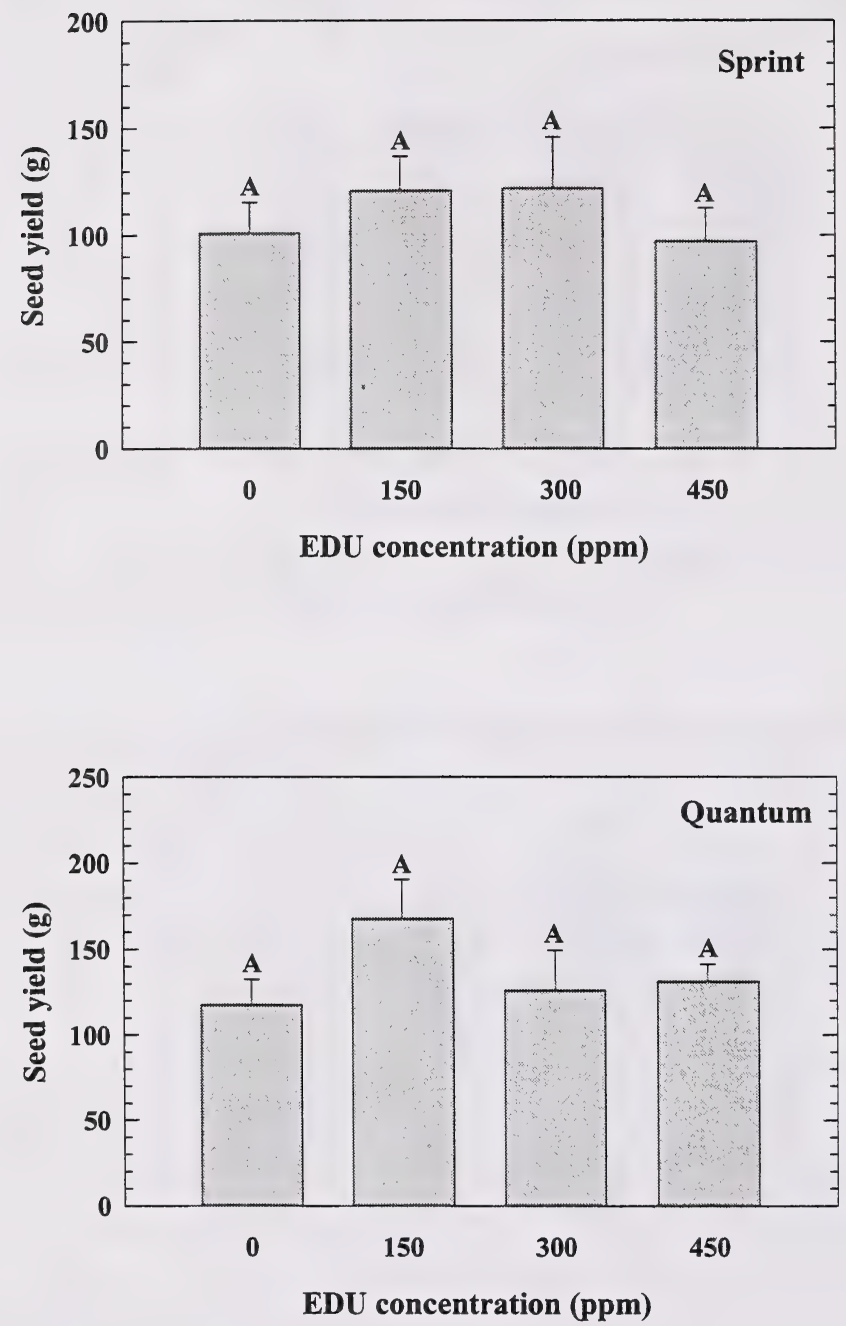

Values are means $\pm \mathrm{SE}$. Bars bearing letters that differ from controls ( $0 \mathrm{ppm}$ EDU) are significantly different at $\mathrm{P} \geq 0.95$. $\mathrm{N}=4$

Figure 9 Seed yields of canola cvs. Sprint and Quantum treated with different levels of EDU 


\begin{tabular}{|c|c|c|c|c|}
\hline $\begin{array}{l}\text { EDU Conc. } \\
\text { (ppm) }\end{array}$ & $\begin{array}{c}\text { Plant Height } \\
\text { (cm) }\end{array}$ & $\begin{array}{c}\text { AG Biomass } \\
\text { (g) }\end{array}$ & Seed Number & $\begin{array}{c}\text { Seed Size }(\mathrm{g}) \\
\text { (weight per } 1000 \\
\text { seeds) }\end{array}$ \\
\hline 0 & $\begin{array}{l}103.2 \pm 2.0 \\
\mathrm{~A}\end{array}$ & $\begin{array}{l}429.8 \pm 47.4 \\
\text { A }\end{array}$ & $\begin{array}{l}32616 \pm 3970 \\
\text { A }\end{array}$ & $\begin{array}{l}3.1 \pm 0.1 \\
\text { A }\end{array}$ \\
\hline 150 & $\begin{array}{l}110.5 \pm 1.1 \\
\text { A }\end{array}$ & $\begin{array}{l}465.0 \pm 33.2 \\
\text { A }\end{array}$ & $\begin{array}{l}35475 \pm 3750 \\
\text { A }\end{array}$ & $\begin{array}{l}3.4 \pm 0.1 \\
\mathrm{~A}\end{array}$ \\
\hline 300 & $\begin{array}{l}107.1 \pm 1.1 \\
\text { A }\end{array}$ & $\begin{array}{l}471.0 \pm 60.2 \\
\text { A }\end{array}$ & $\begin{array}{l}37488 \pm 7077 \\
\text { A }\end{array}$ & $\begin{array}{l}3.2 \pm 0.1 \\
\mathrm{~A}\end{array}$ \\
\hline 450 & $\begin{array}{l}106.6 \pm 0.8 \\
A\end{array}$ & $\begin{array}{l}414.5 \pm 38.1 \\
\mathrm{~A}\end{array}$ & $\begin{array}{l}30870 \pm 5260 \\
\mathrm{~A}\end{array}$ & $\begin{array}{l}3.2 \pm 0.1 \\
\mathrm{~A}\end{array}$ \\
\hline
\end{tabular}

Values are means \pm SE. Within each column, values bearing letters that differ from controls $(0 \mathrm{ppm}$ EDU) are significantly different at $\mathrm{P} \geq 0.95$. Plant heights, $N=48$; all others $N=4$

Table $7 \quad$ Vegetative and reproductive parameters of canola cv. Quantum

\begin{tabular}{|c|c|c|c|c|}
\hline $\begin{array}{l}\text { EDU Conc. } \\
\text { (ppm) }\end{array}$ & $\begin{array}{l}\text { Plant Height } \\
\text { (cm) }\end{array}$ & $\begin{array}{c}\text { AG Biomass } \\
\text { (g) }\end{array}$ & Seed Number & $\begin{array}{c}\text { Seed Size }(\mathrm{g}) \\
\text { (weight per } 1000 \\
\text { seeds) }\end{array}$ \\
\hline 0 & $\begin{array}{l}117.4 \pm 1.1 \\
\text { A }\end{array}$ & $\begin{array}{l}462.9 \pm 43.1 \\
\text { A }\end{array}$ & $\begin{array}{l}38093 \pm 4438 \\
\text { A }\end{array}$ & $\begin{array}{l}3.1 \pm 0.1 \\
\mathrm{~A}\end{array}$ \\
\hline 150 & $\begin{array}{l}120.6 \pm 0.7 \\
\text { A }\end{array}$ & $\begin{array}{l}493.7 \pm 29.4 \\
\text { A }\end{array}$ & $\begin{array}{l}56341 \pm 6160 \\
\text { A }\end{array}$ & $\begin{array}{l}3.0 \pm 0.1 \\
\text { A }\end{array}$ \\
\hline 300 & $\begin{array}{l}119.6 \pm 0.7 \\
\text { A }\end{array}$ & $\begin{array}{l}497.4 \pm 51.8 \\
\text { A }\end{array}$ & $\begin{array}{l}41050 \pm 7373 \\
A\end{array}$ & $\begin{array}{l}3.1 \pm 0.0 \\
\text { A }\end{array}$ \\
\hline 450 & $\begin{array}{l}117.3 \pm 0.6 \\
\mathrm{~A}\end{array}$ & $\begin{array}{l}473.6 \pm 20.0 \\
\text { A }\end{array}$ & $\begin{array}{l}43130 \pm 1973 \\
A\end{array}$ & $\begin{array}{l}3.0 \pm 0.1 \\
\mathrm{~A}\end{array}$ \\
\hline
\end{tabular}

Values are means $\pm \mathrm{SE}$. Within each column, values bearing letters that differ from controls ( $0 \mathrm{ppm} \mathrm{EDU})$ are significantly different at $P \geq 0.95$. Plant heights, $N=48$; all others $N=4$ 


\subsection{CONCLUSIONS}

A method for field application of EDU was developed and utilized in this study. The procedure employed provided preliminary information on the use of EDU as a protectant against ozone effects on crops. Results of this investigation suggest that EDU either protected plants from ozone or that EDU had positive effects on plant growth itself. Treatment with EDU resulted in significant increases in plant height, seed yield, above-ground biomass, seed number and weight per 1,000 seeds; however, these effects were species- and cultivar-specific, suggesting that doseresponse experiments are necessary to evaluate the effects of ozone on specific cultivars. It is necessary to verify whether the effects of EDU were due to protection against ozone or to plant growth promotion through other effects. Verification should be performed in the presence and absence of ozone in a controlled environment facility. This field study should be repeated at this and other sites in Alberta to verify the repeatability of the results and to gain information on spatial and seasonal variation of ozone and EDU effects. The concentration range of EDU used should be adjusted to include a treatment lower than $150 \mathrm{ppm}$, perhaps $75 \mathrm{ppm}$. While interesting trends emerged from this study, statistical significance of EDU effects was rarely found. This suggests that the power of the experiment should be increased. This could be achieved by increasing the number of samples. 


\subsection{REFERENCES}

Archambault DJ, Li X and Slaski JS (2000) Ozone protection in plants - The potential use of chemical protectants to measure atmospheric oxidant damage in Alberta crops. Final report. A literature review prepared for Alberta Environment. Pp. 61.

CASA (2000) Ozone data for Fort Saskatchewan Monitoring Station, May - September, 2000 (www.casahome.org). Accessed January 17, 2001.

Foster KW, Guerard JP, Oshima RJ, Bishop JC and Timm H (1983) Differential ozone susceptibility of centennial russet and white rose potato as demonstrated by fumigation and antioxidant treatments. American Potato Journal 60: 127-139.

Legassicke BC and Ormrod DP (1981) Suppression of ozone-injury on tomatoes by ethylene diurea in controlled environments and in the field. HortScience 16(2): 183-184.

Little TM and Hills FJ (1978) Agricultural experimentation. design and analysis. John Wiley and Sons, Inc. New York. Pp. 350.

Manning WJ (1995) Use of protective chemicals to assess the effects of ambient ozone on vegetation. Proceedings of the $88^{\text {th }}$ Annual Meeting of the Air \& Waste Management Association Pp. 12.

Manning WJ and Krupa SV (1992) Experimental methodology for studying the effects of ozone on crops and trees. In: Surface level ozone exposures and their effects on vegetation. (AS Lefohn ed.) p.93-156.

Sandhu HS (1999) Ground-level ozone in Alberta. Report prepared for Science and Technology Branch, Alberta Environmental Protection, No. 1494-A9901, Edmonton, Alberta. Pp. 66. 

| 